\title{
The algal growth-limiting nutrient of lakes located at Mexico's Mesa Central
}

\author{
Fernando W. BERNAL-BROOKS, ${ }^{*}$ José J. SÁNCHEZ CHÁVEZ, ${ }^{2}$ Luis BRAVO INCLÁN, ${ }^{2}$ \\ Rubén HERNÁNDEZ MORALES, ${ }^{3}$ Ana K. MARTÍNEZ CANO,${ }^{4}$ Owen T. LIND, ${ }^{4,5}$ Laura DÁVALOS-LIND ${ }^{4,5}$
}

${ }^{1}$ Instituto de Investigaciones sobre los Recursos Naturales (INIRENA), Universidad Michoacana de San Nicolás de Hidalgo, Avenida San Juanito s/, Col. Nueva Esperanza, Morelia, Michoacán, 58337 México; ${ }^{2}$ Instituto Mexicano de Tecnología del Agua (IMTA), Paseo Cuauhnahuac 8532, Jiutepec, Morelos, 62550 México; ${ }^{3}$ Laboratorio de Biología Acuática, Facultad de Biología, Universidad Michoacana de San Nicolás de Hidalgo, Av. Francisco J. Múgica s/n Ciudad Universitaria, Morelia, Michoacán, 58030 México; ${ }^{4}$ Centro de Investigaciones Tropicales (CITRO), Universidad Veracruzana, Ex Hacienda Lucas Martín, Privada de Araucarias s/n, Col. Periodistas, 91019 Xalapa Enríquez, Ver., México; ${ }^{5}$ Center for Reservoir and Aquatic Systems Research (CRASR), Baylor University, One Bear Place 97178, Waco, TX 76798-7178, USA

*Corresponding author: fbernalbrooks@gmail.com

\begin{abstract}
This paper reports on the algal growth-limiting nutrients of five lakes located on Mexico's Mesa Central - a topic poorly known in the regional limnology of Mexico. The five case studies involved three contiguous watersheds of Michoacán State and provided a trophic state variation from mesotrophic to hypereutrophic; the case studies included Lakes Zirahuén, Pátzcuaro, Teremendo, Cuitzeo and the Cointzio Reservoir. The fieldwork involved the collection of physical and chemical data (including nutrients) from each case study during the dry and rainy seasons of 2010. Additionally, water samples $(1 \mathrm{~L})$ were obtained and filtered $(0.45 \mu \mathrm{m})$ in the laboratory to keep the nutrient content available for bioassays. The chemical analyses suggested a phosphorus (P) limitation in the Cointzio Reservoir, Lake Teremendo and Lake Zirahuén relative to an N:P>16:1. There was a nitrogen $(N)$ limitation at three sampling stations of Lake Pátzcuaro, with an N:P<16:1. As result of the bioassays conducted in July 2012, the Cointzio Reservoir and Lake Teremendo appeared to be P-limited and Lake Pátzcuaro appeared to be N-limited at three sampling stations. Lake Zirahuén showed seasonal variation, with an $N$ limitation during the dry season and a P limitation during the wet season. Those cases with similar results from both methods confirmed the limiting nutrient identification. Lake Cuitzeo, Lake Zirahuén (dry season), and the shallowest sampling station in Lake Pátzcuaro produced unclear results because of divergent outcomes. In terms of the algal growth potential, the Cointzio Reservoir remained unaltered from one season to the next. However, for most of the lakes (with the exception of Lake Pátzcuaro sites 2 and 4), the rainy season provided a dilution effect. Effective lake management depends on a clear recognition of such elements that are in control of the aquatic productivity. In the area of Michoacán, both $N$ and P may act as limiting nutrients.
\end{abstract}

Key words: Tropical lakes; algal bioassays; limiting nutrient; Mexico limnology; endorheic basins; Michoacán.

Received: March 2015. Accepted: January 2016.

\section{INTRODUCTION}

The successful synthesis of phytoplankton protoplasm via primary production is determined by the availability of the elements in the stoichiometric proportion that is characteristic of that protoplasm. Theoretically, the element in control of the productivity follows Liebig's Law of the Minimum, which states that the element with the least availability relative to the organism's needs becomes limiting (Liebig, 1842). The growth of phytoplankton populations is a product of this protoplasm synthesis rate (bottom-up control), as governed by loss to grazing (topdown control). Certainly, excessive fertility with a high nutrient availability leads to a state of eutrophication, with numerous undesirable consequences for those relying on the water resource. Political concerns for local, state or federal governments are derived from unpleasant cultural impacts with economic implications, especially within tourism areas under public scrutiny.
However, why is it of large relevance as to which nutrient is limiting aquatic productivity for lakes management in Mexico? Traditionally, Mexican limnology was rather descriptive and consisted of the monitoring of physical and chemical components (Dávalos-Lind and Lind, 1993). The country, rather dry and scant of water bodies, along with a poorly developed limnological background, still depends on textbooks available in English that provide primarily temperate lake examples (Alcocer and Bernal-Brooks, 2010). As an influence from overseas, the widespread idea of phosphorus as the limiting nutrient in North American waters (Elser et al., 1990; Schindler et al., 2008) still prevails in Mexico, despite the conclusion that the eutrophication of lakes cannot be controlled only by focusing on phosphorous but also by focusing on nitrogen (Lewis and Wurtsbaugh, 2008). Actually, the tropical zones include lakes, where the element in control of the aquatic productivity is nitrogen (Henry et al., 1985; 
Wurtsbaugh et al., 1985; Dávalos et al., 1989; RamosHiguera et al., 2008), and even both elements (phosphorus and nitrogen) may act simultaneously in an effect called co-limitation (Hernández et al., 2001). Further, the nutrient limitation may temporarily change from one element to the other within the same subtropical lake (Havens 1994). The clay turbidity that is typical of shallow Mexican lakes may also interfere with nutrient uptake at the autotrophic level (Lind et al., 1992).

The present study incorporated past studies for the Mesa Central area to provide an answer about a common limiting nutrient of aquatic productivity and the seasonal differences in algal growth potential (AGP) or fertility (i.e., the amount of nutrients available to produce eutrophication). Previous research on the lake waters in Mexico's Mesa Central found variable results for the limiting nutrient as well as a dilution of AGP with the presence of rains (Hernandez et al., 2001; Davalos et al., 2013). However, as the structure and function of dynamic aquatic ecosystems may be altered over time (i.e., over decades) (Alcocer and Bernal-Brooks, 2009) by man-made impacts, the present study procured an approximate comparison with past studies in order to provide a long-term perspective of AGP and the limiting nutrient.

Attempts to unveil the limiting nutrient of aquatic ecosystems follow two different approaches, which are the $\mathrm{N}: \mathrm{P}$ ratio or stoichiometric relationship (the proportion of nitrogen and phosphorus) of lake waters (Planas and Moreau, 1990) and bioassays. Bioassays experimentally use a test organism under laboratory conditions that proliferates with the nutrients available in the samples (algal growth potential) or with the selective addition of phosphorus and/or nitrogen, as they are the most common limiting elements. Two questions arise in terms of methodology. First, does the N:P ratio predict the outcome of the algal bioassays and reinforce the results? Second, is there a significant change in the limiting nutrient of those lakes under study relative to past conditions?

\section{METHODS}

\section{Study area}

The East-West Volcanic Axis (EWVA, also known as Trans Mexican Volcanic Belt) includes highlands in Central Mexico located from the Pacific coast to the Gulf of Mexico, with numerous volcanic mountains of Tertiary and Quaternary origin (Demant, 1975). The lakes in the study area (Fig. 1, Tab. 1) are on the western side of the EWVA in the federal state of Michoacán, within three contiguous endorheic watersheds of tectonic/volcanic origin fed by direct/indirect atmospheric precipitation and minor inflow or runoff tributaries. At the Lerma-Santiago Pacific region, an average of $816 \mathrm{~mm}$ of rain fell for the period from 1971 to 2000 (CONAGUA, 2011), and this was the main water source in a rather dry country.
Lake Cuitzeo, the largest of the five lakes $\left(375 \mathrm{~km}^{2}\right)$, contains the shallowest maximum depth (approximately $2.3 \mathrm{~m}$ at maximum level). Despite the origin as a closed basin, a man-made channel at the northern point, known as La Cinta, diverts the excess volume during the rainy season to the next federal state (Guanajuato). The latter was undertaken in order to prevent floods in the rich agricultural fields located at the southern shoreline. Lake Cuitzeo and Lake Pátzcuaro maintain continuous warm polymictic mixing regimes relative to their maximum lengths (50.9 km and $16.2 \mathrm{~km}$, respectively). In contrast, Lake Zirahuén (the deepest lake), and the small crater lake of Teremendo ( $4.7 \mathrm{~km}$ and $0.5 \mathrm{~km}$, respectively), are both surrounded by extinct volcanic prominences, and they thermally stratify from March to October, as is typical of warm monomictic types.

The Cointzio Reservoir, the only artificial water body included in the study $(5.5 \mathrm{~km}$ at maximum length at its maximum water level), maintains an unstable thermal profile from June to December comparable to a fluvial system, while stratifying during the rest of the year and exhibiting typical lacustrine characteristics (Susperregui et al., 2009). This artificial lake contains the water supply for Morelia, the main city of Michoacán, and it maintains a fast hydric renewal relative to the other lakes in this study.

\section{Sampling}

Water samples were taken at the lake surface by means of a Van Dorn sampler (Wildco, Yulee, Fl, USA). Due to the heterogeneity already detected in previous research (Alcocer and Bernal Brooks, 2002), two and four sites were sampled in Lakes Cuitzeo and Pátzcuaro, respectively. In Lakes Zirahuén and Teremendo, only one sampling station was considered at the deepest point of the lake. In the Cointzio Reservoir, water samples were taken from in front of the dam. In general, the temporal variation involved two counterparts, the dry season (24-27 May, 2010) and the rainy season (25-29 October, 2010) (Tab. 1).

At all of the sampling stations, in situ measurements of Secchi disc transparency, temperature, dissolved oxygen, conductivity and $\mathrm{pH}$ were obtained by means of a HANNA multiparameter probe HI 9828 (Woonsocket, RI, USA). Water samples for the chemical analysis and bioassays were obtained during the morning hours at the lakes/reservoir surface, stored in polyethylene bottles and kept in an ice box at a low temperature near the freezing point and in dark conditions in order to preserve the chemical constituents as much possible. Then, the samples were taken to the laboratory and analyzed in the afternoon. For the bioassays, the water samples were filtered through $0.45 \mu \mathrm{m}$ glass fibre filters (Whatman GF/F), and an approximately one litre subsample was kept frozen, with the nutrients immobilized in such a condition until the samples could be tested during the period from 18-29 


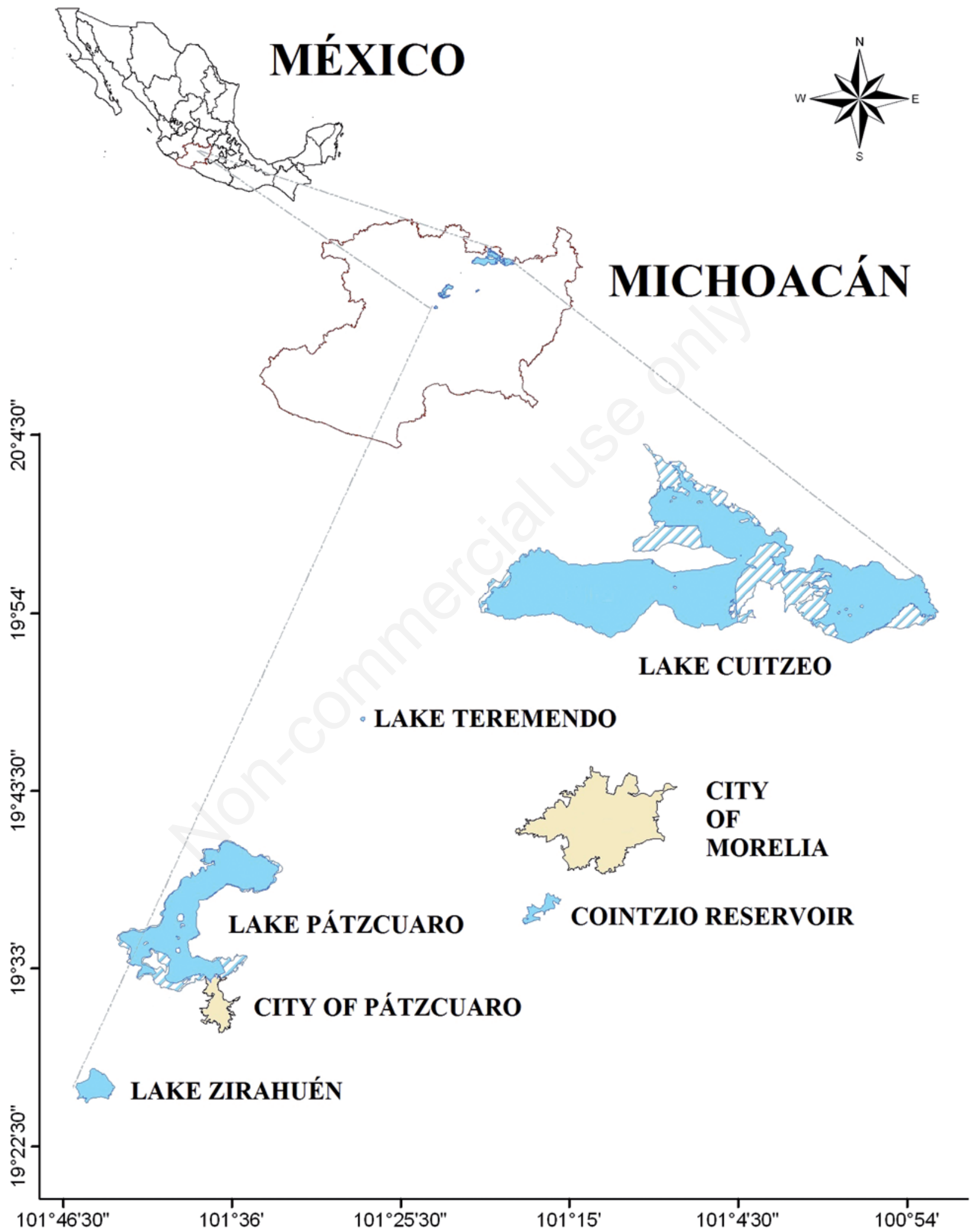

Fig. 1. Lakes and reservoir under study in geographical context. 
July 2012. Based on previous experience (USEPA, 1978, section 3.24 Storage; Avanzino and Kennedy, 1993; Nollet and de Gelder, 2011), the samples stored in this manner remain unaltered for years.

The chemical analysis was undertaken on the following three days after the sampling field work, using the Standard Methods for Water and Wastewater (APHA, 1995 ) as a reference. The analyses included $\mathrm{N}-\mathrm{NO}_{2}, \mathrm{~N}-$ $\mathrm{NO}_{3}, \mathrm{~N}$-Kjeldahl ( $\mathrm{N}$ from organic matter digestion and $\mathrm{N}-$ $\mathrm{NO}_{3} / \mathrm{NH}_{4}$ ), soluble reactive phosphorus (SRP) and total phosphorus (TP). To calculate an approximated N:P ratio, the first three $\mathrm{N}$ variables were added for comparison with the total P. Furthermore, at the laboratory (included in Tab.1), the assessments of the total solids, suspended solids and chlorophyll- $a$ proceeded, according to APHA (1995), with the water subsamples from each station.

The bioassays followed the USEPA (1978) protocol, with Selenastrum capricornutum (Printz) as the indicator organism. This strain was obtained from the Laboratory of Limnology at Baylor University (Texas, USA), and the procedure included a variation introduced by Dávalos et al. (1989) using $50 \mathrm{~mL}$ test tubes (to maximize space for incubation) with a polyurethane sponge on top and a 40:60 water sample/air proportion (López-López and Dávalos-Lind, 1998; Millican et al., 2008). For each lake, the algal growth was registered for five conditions and four replicates: lake water without nutrients added (socalled algal growth potential or AGP), full-nutrient culture media, lake water with nitrogen $(\mathrm{N})$ added, lake water with phosphorus $(\mathrm{P})$ added, and lake water with both $\mathrm{N}$ and $\mathrm{P}(\mathrm{NP})$ added. After the inoculation of S. capricornutum, the tubes were distributed in a random manner on transparent acrylic trays designed to support 20 tubes, each one lying with such a slight angle to maximize the water surface exposure to the air inside the tube. Several 20-tube trays were kept inside an incubator at a constant temperature of $24 \pm 0.2^{\circ} \mathrm{C}$ and continuous illumination with cool-white lamps at $4300 \pm 10 \%$ lux (USEPA, 1978), until the maximum population growth was attained. Daily measurements of biomass (as chlorophyll $a$ ) were obtained by fluorometer measurements (Turner DesignsTD700, Sunnyvale, CA, USA) and the previous mixing of the contents of each tube with a vortex. The identification of the limiting nutrient relied on differential curve slopes analyzed statistically by one-way ANOVA and a post hoc Duncan's test $(\mathrm{P}<0.05)$ included in Statistica version 10 (Tulsa, OK, USA).

\section{Comparative information}

For Lake Pátzcuaro in particular, the availability of physical and chemical data for 1998 (Alcocer and BernalBrooks, 2002) enabled a comparison with those obtained by IMTA (unpublished) in 2006-2010. Therefore, a statistical $t$-test $(\mathrm{P}<0.05)$ was applied to the independent samples (1998 vs 2006-2010) for Secchi disc transparency, chlorophyll- $a$, total nitrogen, soluble reactive phosphorus and total phosphorus.

\section{RESULTS}

The physical and chemical variables registered showed a variation between mesotrophic and hypertrophic systems, which was slightly different than previous reports for Lake Zirahuén (oligo-mesotrophic, Tab. 1). Even so, the latter still appeared as the less enriched water body with the most transparent waters $(>3 \mathrm{~m})$ and a chlorophyll- $a$ content near the limit of detection $\left(<5 \mu \mathrm{g} \mathrm{L}^{-1}\right)$, while the shallowest aquatic environments of Lakes Cuitzeo and Pátzcuaro site 1 had low Secchi disc transparencies $(0.15 \mathrm{~m}$ or less, during the dry season), along with the highest total solids $\left(>3000 \mathrm{mg} \mathrm{L}^{-1}\right)$, suspended solids (>700 $\left.\mathrm{mg} \mathrm{L}^{-1}\right)$ and chlorophyll- $a\left(250 \mu \mathrm{g} \mathrm{L}^{-1}\right.$, Lake Cuitzeo site 1 rainy season) contents. In a middle range, the data for the three stations of Lake Pátzcuaro (2 to 4) exemplify a mixture of rather turbid and fertile environments ( $<10 \mathrm{~m}$ depth). Lake Teremendo, which was previously reported as eutrophic, attained high chlorophyll- $a$ values $\left(>60 \mu \mathrm{g} \mathrm{L}^{-1}\right)$ in combination with low transparencies (0.2-0.4 m) of biogenic turbidity (Tab. 1). In contrast, the Cointzio Reservoir maintained turbid conditions of terrestrial origin relative to the runoff from surrounding areas, but the trophic assessments indicated eutrophic conditions (Tab. 1). Therefore, a disparity appeared here between the stable amounts of total solids (approximately $300 \mathrm{mg} \mathrm{L}^{-1}$ ) and the variable chlorophyll- $a$ content ( 5 and $17 \mu \mathrm{g} \mathrm{L}^{-1}$ ) detected in the present study. The chemical analysis for nutrients (Tab. 2) showed a group of samples with an $\mathrm{N}: \mathrm{P}>16$, suggesting $\mathrm{P}$ limitation (Lakes Teremendo, Cointzio and Zirahuén), while an $\mathrm{N}: \mathrm{P}<16$ suggested $\mathrm{N}$ limitation (Lake Pátzcuaro sites 1-4 for the dry season; sites 1, 2 and 4 for the rainy season). Variable results appeared for Lake Cuitzeo ( $\mathrm{N}$ is limiting in the dry season, $\mathrm{P}$ in the rainy season) and Lake Pátzcuaro site 3 ( $\mathrm{N}$ is limiting in the dry season, $\mathrm{P}$ in the rainy season).

Both methodologies applied during the present study (i.e., chemical stoichiometry and bioassays) converged and reinforced the identification of the limiting nutrient in the following cases (Figs. 2 a-c): Lakes Cointzio and Teremendo (P limitation), the three stations of Lake Pátzcuaro (N limitation) and one seasonal component of Lakes Zirahuén and Cuitzeo ( $\mathrm{P}$, rainy season), respectively.

For Lake Cuitzeo, the N:P ratio suggested a temporal variation between $\mathrm{N}$ (drought) and $\mathrm{P}$ (rain), while the bioassay's counterpart remained unclear for the first seasonal component. Furthermore, in the case of Lake Pátzcuaro site 1, the chemical analysis $(\mathrm{N}: \mathrm{P}<1: 16)$ suggested $\mathrm{N}$ limitation and coincided with the results obtained by bioassays for the rest of the lake stations (2-4). Notwithstanding, both the N:P ratio and the experimental 


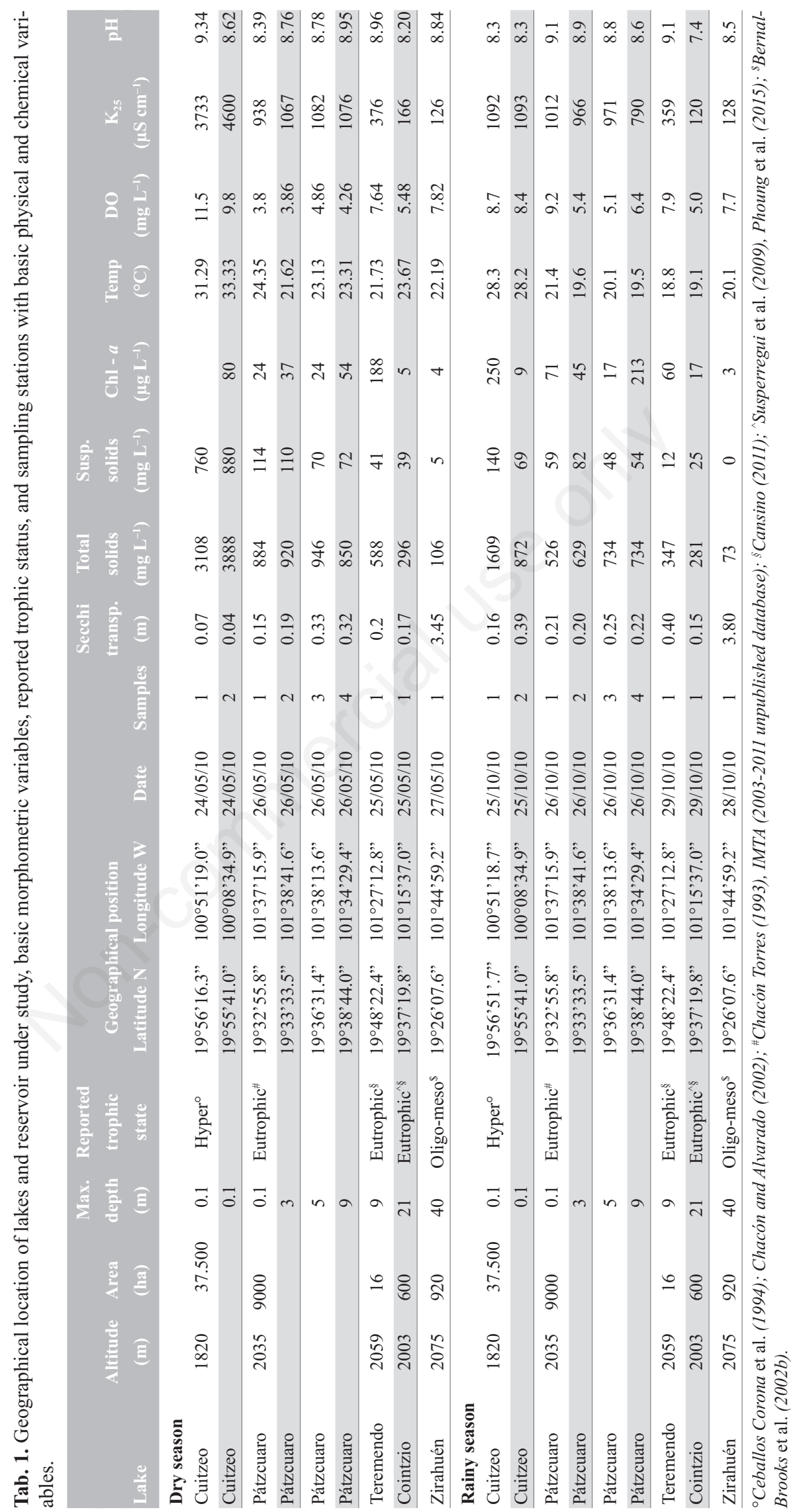


test rendered opposite results for the dry season ( $\mathrm{N}$ and NP). Thus, the two samples previously mentioned (Lakes Cuitzeo and Pátzcuaro 1) demand further investigation in order to clarify the nutrient limitation.

Following the alternation between dry and wet seasons (November to April and May to October, respectively), the decrease in fertility with rains reached extremes of 98\% (Lake Zirahuén), 90\% (Lake Cuitzeo) and 85\% (Lake Pátzcuaro-Embarcadero) (Fig. 2a). There were exceptions in that Lake Pátzcuaro 2 and 4 absolutely departed from the expected tendency, and the Cointzio Reservoir remained more or less unaltered for the two seasonal data, probably because of the water renewal.

\section{DISCUSSION}

We acknowledge our limited number of samples (spatially and temporarily); therefore, the inference from data taken at only two time periods should be interpreted carefully.

Thus, on the basis of physical and chemical information, the evidence obtained in this research confirmed the description given for the lakes in the area by previous studies (Tab. 1), except for two cases.

Lake Zirahuén underwent changes in Secchi disc transparency (6 $\mathrm{m}$ in $1987 v s$ 3.45-3.80 $\mathrm{m}$ in 2010) and chlorophyll- $a\left(1.25-2.25 \mu \mathrm{g} \mathrm{L}^{-1}\right.$ in $1987 v s$ 3-4 $\mu \mathrm{g} \mathrm{L}^{-1}$ for the present study) (Bernal-Brooks, 1988 vs the present study, respectively). Lake Pátzcuaro (Tab. 3) also lost Secchi disc transparency in the deepest areas (A and B). The higher levels of soluble reactive phosphorus and total phosphorus concentrations, in general (Alcocer and Bernal-Brooks, 2002 vs IMTA 2006-2010, unpublished information, respectively), suggested a change from an $\mathrm{NP}$ to an $\mathrm{N}$ limitation. To answer the first question put forth in the introduction of this paper (i.e., does the N:P ratio calculated from chemical analysis match the outcome of the algal bioassays and reinforce the results?), for most samples, both methodologies lead to the same results, with exceptions. The data suggested that the test organism, S. capricornutum, grew under specific physical and chemical conditions that the shallow environments of Lakes Michoacán, Cuitzeo (drought) and Pátzcuaro 1 fail to meet, probably because of the slightly saline conditions or colloidal components distressing the algal populations' development inside the tubes.

With respect to the second question (i.e., is there a significant change in the limiting nutrient of those lakes under study relative to past conditions?), previous research on the Mesa Central water ecosystems revealed a spatial variation from lake-to-lake in the limiting nutrient. P-limitation, without temporal variation, was characteristic of Lakes Teremendo and Cuitzeo and the Cointzio Reservoir (Hernández et al., 2001). For the first and third study cases, our study reached the same previous conclu-

Tab. 2. $\mathrm{N}$ and $\mathrm{P}$ concentrations analyzed for each sample and fraction under study and an assumption of the limiting nutrient based on the stoichiometric ratio.

\begin{tabular}{|c|c|c|c|c|c|c|c|c|}
\hline Lake/Reservoir & $\begin{array}{l}\text { N-Kjeldahl } \\
\left(\mathrm{mg} \mathrm{L}^{-1}\right)\end{array}$ & $\begin{array}{l}\mathrm{N}-\mathrm{NO}_{3} \\
\left(\mathrm{mg} \mathrm{L}^{-1}\right)\end{array}$ & $\begin{array}{l}\mathrm{N}-\mathrm{NO}_{2} \\
\left(\mathrm{mg} \mathrm{L}^{-1}\right)\end{array}$ & $\begin{array}{c}\mathrm{P}_{-} \mathrm{PO}_{4} \text { (ortho) } \\
\left(\mathrm{mg} \mathrm{L}^{-1}\right)\end{array}$ & $\begin{array}{l}\text { P-total } \\
\left(\mathrm{mg} \mathrm{L}^{-1}\right)\end{array}$ & $\mathrm{N}: \mathrm{P}$ & $\begin{array}{c}\text { Stoichiometric } \\
\text { ratio }\end{array}$ & $\begin{array}{l}\text { Limiting } \\
\text { nutrient }\end{array}$ \\
\hline $\begin{array}{l}\text { Dry season } \\
\text { Cuitzeo } 1\end{array}$ & 15.82 & 2.02 & 0.41 & 1.48 & 1.95 & 9 & $<16: 1$ & $\mathrm{~N}$ \\
\hline Cuitzeo 2 & & 3.63 & 0.09 & 0.26 & 1.24 & & & \\
\hline Pátzcuaro 1 & 1.14 & 0.76 & 0.17 & 0.18 & 0.24 & 9 & $<16: 1$ & $\mathrm{~N}$ \\
\hline Pátzcuaro 2 & 0.9 & 0.08 & $<0.04$ & $<0.07$ & 0.12 & 8 & $<16: 1$ & $\mathrm{~N}$ \\
\hline Pátzcuaro 3 & 0.53 & 0.22 & $<0.04$ & $<0.07$ & 0.53 & 1 & $<16: 1$ & $\mathrm{~N}$ \\
\hline Pátzcuaro 4 & 0.058 & $<0.06$ & $<0.04$ & $<0.07$ & $<0.07$ & & $<16: 1$ & $\mathrm{~N}$ \\
\hline Teremendo & 1.28 & 3.13 & $<0.04$ & $<0.07$ & $<0.07$ & & $>16: 1$ & $\mathrm{P}$ \\
\hline Cointzio & 1.11 & 4.2 & $<0.04$ & $<0.07$ & $<0.07$ & & $>16: 1$ & $P$ \\
\hline Zirahuén & 0.7 & $<0.06$ & $<0.04$ & $<0.07$ & $<0.07$ & & $>16: 1$ & $\mathrm{P}$ \\
\hline $\begin{array}{l}\text { Rainy season } \\
\text { Cuitzeo } 1\end{array}$ & 6.9 & 0.86 & 0.06 & 0.2 & 0.44 & 18 & $>16: 1$ & $\mathrm{P}$ \\
\hline Cuitzeo 2 & 1.39 & 1.3 & 0.08 & 0.99 & 1.07 & 3 & $<16: 1$ & $\mathrm{~N}$ \\
\hline Pátzcuaro 1 & 0.53 & 2.59 & 0.06 & $<0.07$ & 0.23 & 14 & $<16: 1$ & $\mathrm{~N}$ \\
\hline Pátzcuaro 2 & 0.4 & 1.73 & $<0.04$ & $<0.07$ & 0.19 & 11 & $<16: 1$ & $\mathrm{~N}$ \\
\hline Pátzcuaro 3 & 2.91 & 1.33 & $<0.04$ & $<0.07$ & 0.16 & & $>16: 1$ & $\mathrm{P}$ \\
\hline Pátzcuaro 4 & 1.13 & 1.62 & $<0.04$ & $<0.07$ & 0.3 & 9 & $<16: 1$ & $\mathrm{~N}$ \\
\hline Teremendo & 1.32 & 0.69 & $<0.04$ & $<0.07$ & $<0.07$ & & $>16: 1$ & $\mathrm{P}$ \\
\hline Cointzio & 0.6 & 1.69 & 0.06 & $<0.07$ & $<0.07$ & & $>16: 1$ & $\mathrm{P}$ \\
\hline Zirahuén & 0.42 & 0.09 & $<0.04$ & $<0.07$ & $<0.07$ & & $>16: 1$ & $\mathrm{P}$ \\
\hline
\end{tabular}


sion. Especially in the case of the Cointzio Reservoir, the conclusions of López-López and Dávalos Lind (1998) and Hernández et al. (2001) corresponded with the present study. However, López and Dávalos Lind (1998) found an interesting spatial variation of the limiting nutrient (including $\mathrm{N}$ ) at a wider geographical scale beyond the water body, including the tributary and the outlet. $\mathrm{N}$ limitation also occurred in some cases (Dávalos, 1989, Hernández et al., 2001; Ramos-Higuera et al., 2008) as well as NP co-limitation (Bernal-Brooks et al., 2002a, 2003).

For Lake Pátzcuaro, the results obtained here deviated from the previous study (Bernal-Brooks et al., 2003), as the open waters showed an $\mathrm{N}$ limitation consistently for Lake Pátzcuaro 2, 3 and 4.

For Lake Zirahuén, the limiting nutrient changed from an NP co-limitation (Hernández et al., 2001; BernalBrooks et al., 2002a) to a currently temporal variation, $\mathrm{N}$ limitation during the drought and $\mathrm{P}$ limitation during the rainy season.

The latter two case studies reinforced the progress of eutrophication in the area, which seemed to reach unprecedented situations of human impact. The climatic influence in the region over the water bodies maintained an approximate similarity relative to previous studies, with direct/indirect precipitation as the main water source. The lakes' fertility, which is usually considered high at sites with an $\mathrm{N}$-limitation and low at sites with a P-limitation (in general) for the Mesa Central (Hernández et al., 2001), failed to predict the case of Lake Teremendo, which maintained eutrophic conditions the entire time, despite a P limitation.

\section{CONCLUSIONS}

The eutrophication of water bodies ranks as a worldwide problem. A country such as Mexico, with scarce aquatic resources, should follow an extremely careful management plan to preserve the hydric reserves in view of the water demand from developing human societies established in predominantly arid territories. Moreover, the wastewaters derived from human activities not only constrain water use, but the damage to the water quantity/quality progressively deteriorates the availability of water sources and the habitat of numerous aquatic organisms.

The identification of the limiting nutrient at the autotrophic level becomes an imperative matter in determining which element must be under control to constrain eutrophication and what appropriate technological strategy should be used to control the element. A holistic approach towards a sustainable scenario also demands the contribution of other disciplines, such as the social sciences.

Notwithstanding, the present study concerning the limiting nutrients in the aquatic ecosystems of Central Mexico included five case studies and demonstrated that two elements, $\mathrm{N}$ and $\mathrm{P}$, may take part alternately or simultaneously in the regulation of the algal growth at the base of the food chain, with two outstanding situations showing the importance of limnological studies in the region.

In the case of Lake Pátzcuaro, a comparison of data obtained by Alcocer and Bernal-Brooks (2002) and data from IMTA (2006-2010, unpublished, Tab. 3) revealed an increase in $\mathrm{P}$ loading associated with a change in the limitation from NP to N detected in the present study. Additionally, in the background, the water level of Lake Pátzcuaro dropped six metres since the early 1940s (Bernal-Brooks et al., 2002b). Thus, both the aforementioned features articulated each other to produce severe impacts for the aquatic ecosystem and new in-lake scenarios of stress for the local species.

\section{a. ALGAL GROWTH POTENTIAL}

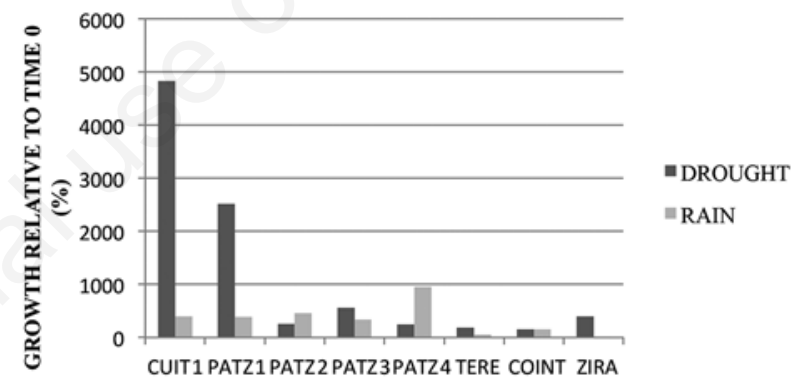

b. DRY SEASON

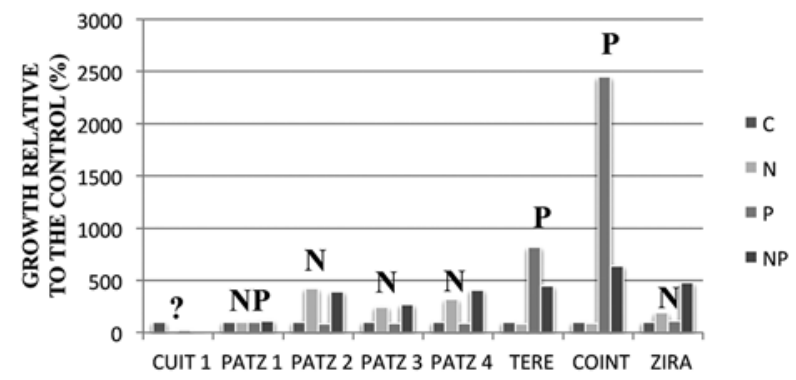

\section{c. RAINY SEASON}

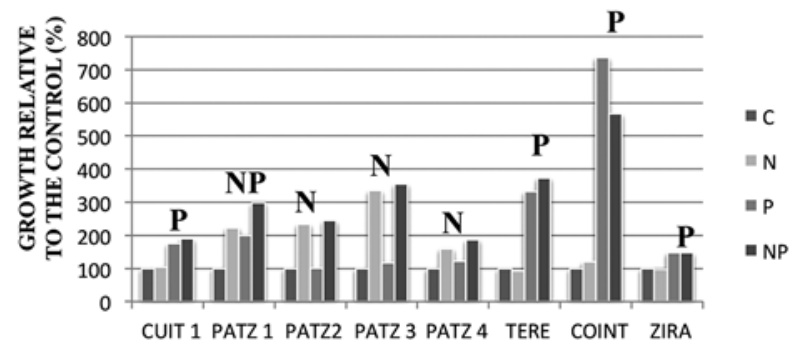

Fig. 2. Percentage of growth relative to the control for (a) Algal growth potential with no additional nutrient addition (a) and the limiting nutrient of algal productivity based on S. capricornutum bioassays during dry (b) and rainy seasons (c) of 2010. 


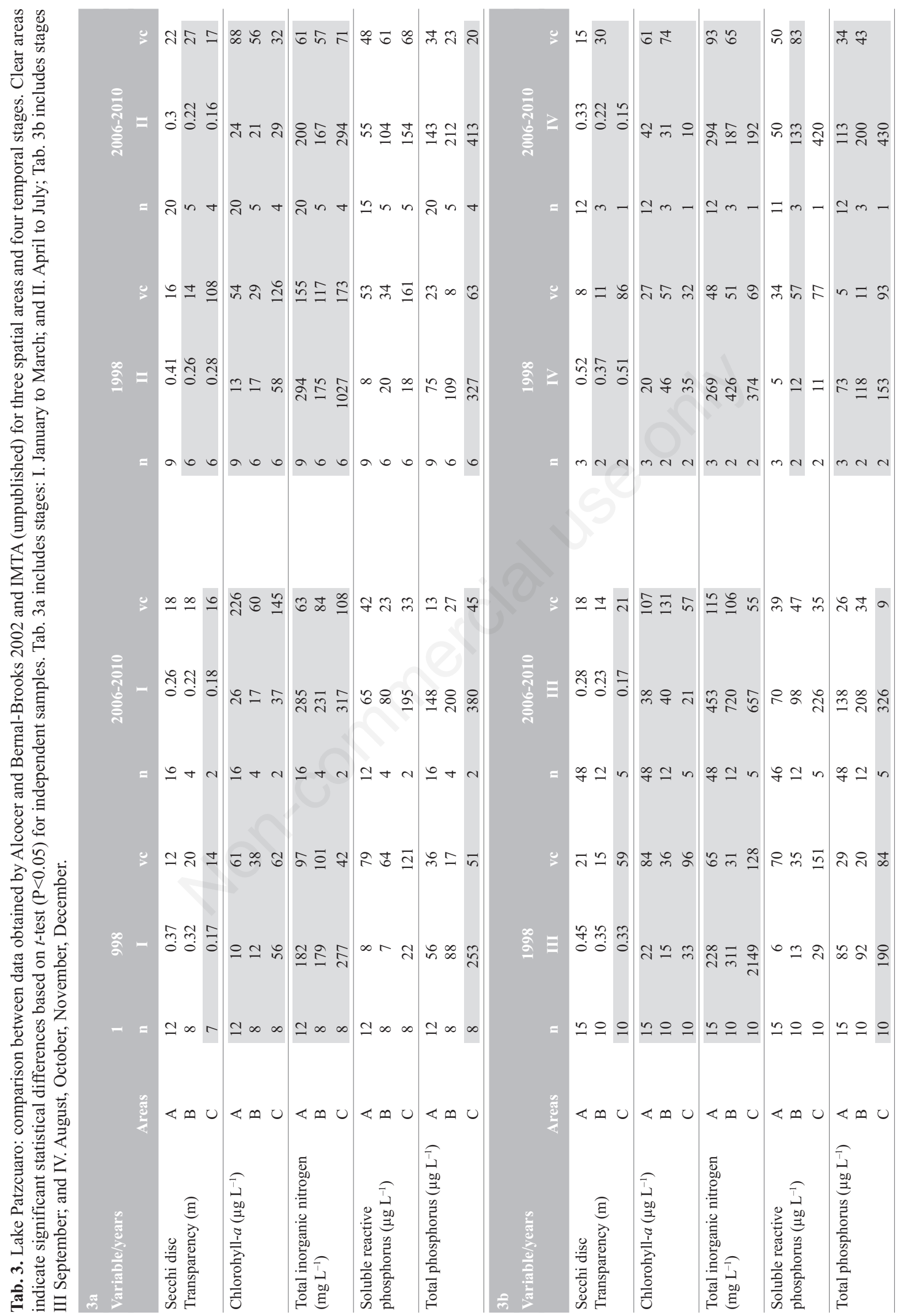


In turn, Lake Zirahuén, the so-called blue lake, has lost its oligo-mesotrophic status (Bernal-Brooks 1988, 2002a) and has become rather eutrophic. The change of an NP to a temporal $\mathrm{N}$ limitation during the dry season may indicate the presence of nutrient loadings coming from the watershed, in such amounts that are unable to be assimilated by the lake self-depuration mechanisms. Therefore, the comparison of long-term data during the present study denoted changes in the limiting nutrient for both Lakes Pátzcuaro and Zirahuén and highlighted the ability of dynamic aquatic ecosystems to be altered by eutrophication, with the need for continuous monitoring.

\section{ACKNOWLEDGMENTS}

Centro de Estudios en Medio Ambiente (CEMA, http://cemamexico.com) conducted the water analysis for nutrients as a certified laboratory. The Limnology Laboratory of Centro de Investigaciones Tropicales (CITRO), Universidad Veracruzana (UV) conducted the bioassays. Centro Regional de Investigación Pesquera de Pátzcuaro conducted the additional water analyses.

\section{REFERENCES}

Alcocer J, Bernal-Brooks FW, 2002. Spatial and temporal heterogeneity of physical and chemical variables for an endorheic, shallow water body: Lake Patzcuaro, Mexico. Arch. Hydrobiol. 155:239-25.

Alcocer J, Bernal-Brooks FW, 2009. [Investigación ecológica a largo plazo en cuerpos acuáticos epicontinentales].[Article in Spanish]. Rev. Dig. Univ. UNAM. 10:1-14.

Alcocer J, Bernal-Brooks FW, 2010. Limnology in Mexico. Hydrobiologia 644:15-68.

APHA, 1995. Standard methods for the examination of water and waste-water. $19^{\text {th }}$ edition. American Public Health Association, Washington, DC.

Avanzino RJ, Kennedy VC, 1993. Long-term frozen storage of stream water samples for dissolved orthophosphate, nitrate plus nitrite, and ammonia analysis. Water Resour. Res. 29:3357-3362.

Bernal-Brooks FW, 1988. Limnology of Lake Zirahuen relative to cultural impacts. MSc Thesis, University of Guelph, Canada.

Bernal-Brooks FW, 2002. [La limnología del Lago de Pátzcuaro: una visión alternativa a conceptos fundamentales]. [PhD Thesis in Spanish]. UNAM, México, DF.

Bernal-Brooks FW, Dávalos-Lind L, Lind OT, 2002a. Assessing trophic state of an endorheic tropical lake: the algal growth potential and limiting nutrients. Arch. Hydrobiol. 153:323-338.

Bernal-Brooks FW, Dávalos-Lind L, Lind OT, 2003. Seasonal and spatial variation in algal growth potential and growthlimiting nutrients in a shallow endorheic lake. Lakes Reserv. Res. Manag. 8:83-93.

Bernal-Brooks FW, Gomez-Tagle Rojas A, Alcocer J, 2002 b. Lake Patzcuaro (Mexico): a controversy about the ecosystem water regime approached by field references, climatic variables, and GIS. Hydrobiologia 467:187-197.

Cansino NR, 2011. [Evaluación de la calidad del agua y el es- tado trófico en el lago cráter de Teremendo, Michoacán, México].[Bsc Thesis in Spanish]. University of Michoacán, Mexico.

Chacón Torres A, 1993. Lake Pátzcuaro, Mexico: watershed and water quality deterioration in a tropical high-altitude Latin American lake. Lake Reserv. Manage. 8:37-47.

Chacón Torres A, Alvarado J, 2002. [El lago de Cuitzeo, p. 157169]. In: G. de la Lanza and J.L. García Calderón (eds.), [Lagos y Presas de México].[Book in Spanish]. AGT Ed.r, México, D.F.

Ceballos Corona JGA, Ortega Murillo MR, Medina Nava M, Martínez Trujillo M, Rodríguez Jiménez L, González Santoyo S, 1994. [Análisis Limnológico del Lago de Cuitzeo, Michoacán, México].[Book in Spanish]. Editorial Universitaria, Universidad Michoacana de San Nicolás de Hidalgo, Michoacán, México.

CONAGUA - Comisión Nacional del Agua, 2011. [Atlas del Agua en México].[in Spanish]. Secretaría de Medio Ambiente y Recursos Naturales, México, D.F.

Dávalos-Lind L, Lind OT, 1993. The changing state of limnology in Mexico: Lake Chapala as an example. Verh. Int. Verein. Limnol. 25:427-430.

Dávalos L, Lind OT, Doyle, RD, 1989. Evaluation of phytoplankton limiting factors in Lake Chapala, México: turbidity and spatial and temporal variations in algal assay response. Lake Reserv. Manage. 5:99-104.

Dávalos-Lind L, Lind OT, Velarde G, Vázques-Rojero E, Thompson J, Hernández G, Sambrano J, Martínez K, Mora López E, 2013. [Aporte de nutrientes de fuentes puntuales y difusas de la subcuenca al lago de Chapala y su potencial para promover crecimiento algal]. In: A. Juárez A (ed.), [Contaminación agrícola y erosión en la cuenca del Lago de Chapala].[Book in Spanish]. FIDERCO, Mexico.

Demant A, 1975. [Les quatre provinces volcaniques du Mexique, relations avec l'evolution geodynamique, depuis le Cretace, II. Les deux provinces occidentales].[Article in French]. C.R. Acad. Sci. 280:1437-1440.

Elser JJ, Marzolf ER, Goldman CR, 1990. Phosphorus and nitrogen limitation of phytoplankton growth in the freshwaters of North America: a review and critique of experimental enrichments. Can. J. Fish. Aquat. Sci. 47:1468-1477.

Havens KE, 1994. Seasonal and spatial variation in nutrient limitation in a shallow sub-tropical lake (Lake Okeechobee, Florida) as evidenced by trophic state index deviations. Arch. Hydrobiol. 131:39-53.

Henry R, Hino K, Tundisi JG, Ribeiro JSB, 1985. Responses of phytoplankton in lake Jacaretinga to enrichment with nitrogen and phosphorus in concentrations similar to those of the River Solimoes (Amazon, Brazil). Arch. Hydrobiol. 103: 453-477.

Hernández-Avilés S, Bernal-Brooks F, Velarde G, Ortíz D, Lind O, Dávalos-Lind L, 2001. The algal growth potential and limiting nutrient of 30 lakes and reservoirs of the Mesa Central of México. Verh. Int. Verein. Limnol. 27:3583-3588.

Lewis W, Wurstbaugh W, 2008. Control of lacustrine phytoplankton by nutrients: erosion of the phosphorus paradigm. Int. Rev. Hydrobiol. 93:446-465.

Liebig J, 1842. [The organische Chemie in ihrer Andwendung auf Physiologie und Pathologie].[Book in German]. Friedrich Bieweg und Sohn, Braunschweig. 
Lind O, Doyle R, Trotter T, Vodopich D, Limón G, Dávalos, L, 1992. Clay turbidity: Regulation of phytoplankton production in a large, nutrient rich tropical lake. Limnol. Oceanogr. 37:549-565.

López-López E, Dávalos-Lind L, 1998. Algal growth potential and nutrient limitation in a tropical river-reservoir system of the Central Plateau, México. Aquat. Ecosyst. Health Manage. 1:1345-1351.

Millican J, Back J, MacFarland AMS, 2008. Nutrient bioassays of growth parameters for algae in the north Bosque river of central Texas. J. Am. Water Resour. Assoc. 44:1219-1230.

Nollet LML, De Gelder LSP, 2011. Handbook of water analysis. CRC Press: 333 pp.

Planas D, Moreau G, 1990. Natural eutrophication in a warm volcanic lake. Verh. Int. Verein. Limnol. 24:554-559.

Phoung TKD, Nemery J, Schmid M, Gratiot N, 2015. Eutrophication of turbid tropical reservoirs: Scenarios of evolution of the reservoir of Cointzio, Mexico. Ecol. Informs. 29:192-205.

Ramos-Higuera E, Alcocer J, Mayagoitia E, Camacho A, 2008. [Nitrógeno: elemento limitante para el crecimiento fito- planctónico en un lago tropical somero].[Article in Spanish]. Hydrobiologica 18:105-113.

Schindler DW, Hecky RE, Findlay DL, Stainton MP, Parker BR, Paterson MJ, Beaty KG, Lyng M, Kasian SEM, 2008. Eutrophication of lakes cannot be controlled by reducing nitrogen input: Results of a 37-year whole ecosystem experiment. P. Natl. Acad. Sci. USA 105:11254-11258.

Susperregui AS, Gratiot N, Esteves M, Prat C, 2009. A preliminary hydrosedimentary view of a highly turbid, tropical, manmade lake: Cointzio reservoir (Michoacán, Mexico). Lakes Reserv. Res. Manag. 14:31-39.

USEPA - United States Environmental Protection Agency, 1978. The Selenastrum capricornutum (Printz) algal assay bottle test: experimental design, application and data interpretation protocol. Document No. 600/9-78-018USEPA, Corvallis, OR, USA.

Wurtsbaugh WA, Vincent WF, Alfaro Tapia R, Vincent CL, Richardson JP, 1985. Nutrient limitation of algal growth and nitrogen fixation in a tropical alpine lake, Lake Titicaca (Peru/Bolivia). Freshwater Biol. 15:185-195. 